\title{
MODEL FOR A SUSTAINABLE ENERGY TRANSITION IN SPAIN. CASE STUDY IN A DISTRICT OF THE BASQUE COUNTRY
}

\author{
JUAN ÁNGEL BALBÁS ${ }^{1}$ \& JOSÉ ALBERTO EGUREN ${ }^{2}$ \\ Mechanical and Manufacturing Department, Mondragón Unibertsitatea, Spain.
}

\begin{abstract}
The current energy model available in Spain is obsolete due to various circumstances, some technological, others social, economic or environmental. This supposes a tension in the economic and social model of the country. Changing the current energy model to an alternative one requires a period of transition. This transition, in turn, requires a planned action and implies the identification of available energy in the vicinity, the awareness and commitment of citizens, the mobilization of technical, technological and economic resources and the design of a generation model and Proximity distribution, efficient. In this new model, compliance with environmental commitments (reduction of GHG emissions) together with the generation of economic activity and the guarantee that the transition will not give rise to any uncertainty regarding the availability and security of supply, must be unquestionable commitments. This document summarizes a research carried out in the Basque Country (Spain), which aims to promote the change of energy model. It presents the different phases of the study carried out, the methodology used, the conclusions, the road map of the transition process, the legislative situation in Spain and some reflections on the research carried out and the results obtained. Also, the study has analyzed the model of energy transition made by five European countries, studying their particularities and the factors that have contributed to the transition and the change of the energy model in them. Models of good practices in Spain have also been studied.

Keywords: Citizen participation, Economic growth, Energy efficiency, Energy policy, Energy transition model, Sustainable energy model.
\end{abstract}

\section{INTRODUCTION}

Spain, one of the European countries with highest dependence on fossil fuels, despite its more than 2,500 hours/year of sunshine in most part of the country, with wind and almost $6,000 \mathrm{~km}$ of coastline, and, despite all that, ranks 13th in the EU in power generation using renewables.

This situation, based on the model for generation, distribution and supply that still persists, has had an increasingly greater impact on the Spanish economic and social model.

The economic impact has manifested itself in numerous companies transferring their production outside Spain due to rising energy costs. And as a result, the loss of competitiveness of our industry or economy [1]. The social impact is manifested in energy poverty (around $11 \%)[2,3]$.

This impact is not necessarily due to a lack of energy or a poorly designed energy generation system. As stated above, the problem lies in the model: oligopolistic and dependent, for the most part, on external sources whose price variability affects the resulting prices applied to consumers. But also, in the structure for the formation of the price of electricity, which is marked by the last source of production that comes into operation: first nuclear energy, then renewables, hydropower, coal (where appropriate) and combined cycles (where appropriate). This is how the Spanish energy mix is generated. In addition to the several types of impact

1 ORCID: https://orcid.org/0000-0002-9702-3684

2 ORCID: https://orcid.org/0000-0002-4127-8776 
described above, non-compliance with the environmental commitments are taken on by Spain, and, as a consequence, the impact on public health.

Moreover, Spanish legislation has maintained an impediment to the development of renewable energies of low powers of small producers, as has been observed in the legal analysis carried out. In Spain, legislation (in force at the time of writing this document) discourages rather than impedes the development of renewable energy, using small facilities (except for own energy generation, since about a few months).

This assertion can be maintained when comparing the current Spanish legal corpus relating to renewables with the legislative evolution of other EU countries.

In Europe, many countries have evolved towards a model of maximum use of renewables, allowing for this (boosting) micro-generation, shared consumption, feeding of surpluses into the grid, etc.

All these countries that have evolved in terms of renewables, first established their energy strategies through models which include mathematical, social, environmental and technological variables (Clean Power Plan, e3-at, LEAP, Energy-Plan, Energiewende, TIMES (ETSAP-TIAM), among others) [4], [5], [6], [7], [8], [9]. Whichever model is used, having one is what matters; it should establish how a country's own resources are used, and it should be aimed at achieving a lower dependence on external energy resources of which the price and supply are controllable, at guaranteeing security of supply, and the possibility of maintaining the desired economic model, in compliance with environmental commitments (reduction of contaminating emissions), bearing in mind the increasingly relevant and more common social aspect: avoiding energy poverty.

This document establishes and presents an action model to promote an energy transition towards renewable energy sources. Part of the model applies to a case study worked in a district of the Basque Country, in which Spanish and Basque (because of the special status of the Basque Autonomous Community) legislation has been analyzed, as well as the existing sensitivity to energy of the Town Councils and citizens. The data obtained have been compared with that obtained from the Renergy project [10]. An analysis of available alternative energy sources has been carried out and an implementation guide has been drafted for four schools.

\section{METHODOLOGY}

The aim of this document is to develop the bases of an energy model based on RES and close to consumption, previously analyzed energy model through the study of several cases. This methodology is schematically presented in Fig. 1.

In phase I of the work, the state of the art in Spain and in the Basque Country has been analyzed. The case analysis methodology has been followed [11], and following the model of industrial ecosystems and regional development $[12,13]$. The work has been developed in a Basque region of high industrial activity of small and medium-sized enterprises (SMEs) and microSMEs, namely the municipalities of Mallabia, Ermua, Eibar, Placencia de Armas, Elgoibar, Mendaro, Deba and Mutriku. The state of the art in Spain, in the Basque Autonomous Community, in five European countries has been studied and different examples of good practice in Spain have been analyzed, all these in phase I of the study. In phase II, a citizen survey has been carried out in the industrial district and an analysis of the municipality. Both results have been compared with the Renergy project and conclusions have been drawn. Subsequently, the previous model was reworked and fieldwork began with an implementation guide. 


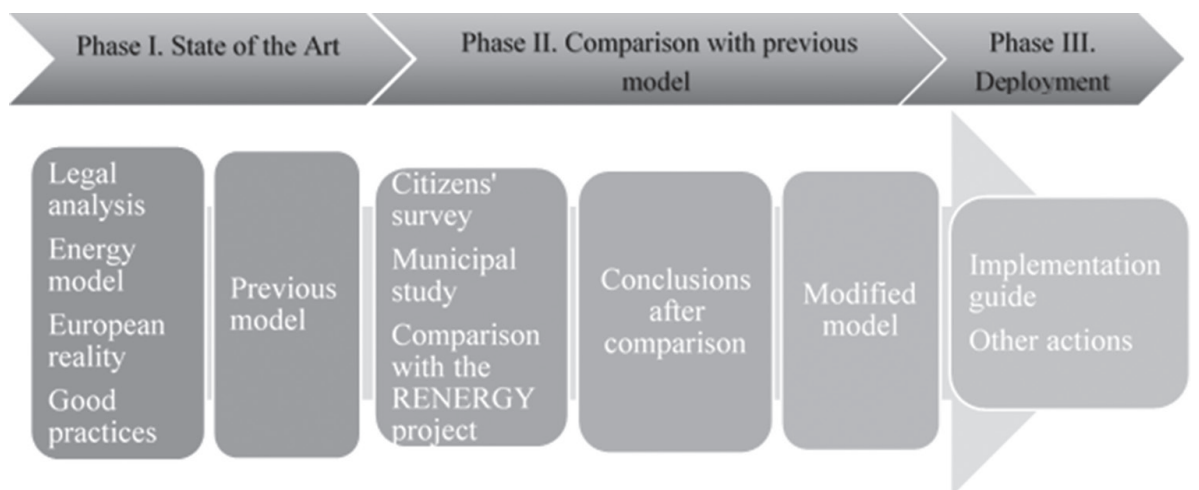

Figure 1: Methodological and phase scheme.

\section{PHASE I. STATE OF THE ART}

3.1 Legal analysis of Spain and the Basque Country (analysis period until July 2018)

The existing competencies on energy (exclusive, shared and executive competences) of the central government as well as of autonomous and local governments were analyzed. The laws and decrees and directives of the EU in force in the field of energy and its most significant points have also been analyzed. The legislative activities carried out by different autonomous communities such as Murcia, Navarre, Catalonia, Cantabria and the Balearic Islands were analyzed as a reference framework for anticipation. Finally, the existing case law of both the Supreme Court and the Constitutional Court has been analyzed.

As a summary of the legal analysis work, we will begin by referring to the initial level of legal certainty and regulatory risk cited by Moreno Berrocal [14] in which the document refers to work carried out by Nomura in 2011 in which seven European countries were analyzed in this respect.

As a conclusion to the exhaustive analysis of all decrees and laws, it becomes clear that none of the 17 Autonomous Communities have any specific or express competence in the field of energy, that is to say, all Autonomous Communities of Spain have the same legislation in this field. However, the respective statutes of autonomy of the Basque Country, Navarre and Murcia recognize exclusive competence in production, transmission and distribution facilities when this transmission does not go beyond the boundaries of the territory and its use does not affect another province or Autonomous Community. The statute of autonomy of Catalonia makes reference to a shared competence with the central government in matters of energy.

The Autonomous Communities of Murcia, Navarra, Extremadura, Balearic Islands, Catalonia and Cantabria have tried to regulate energy matters. All attempts have been appealed to at some point by the central government, resulting in these initiatives being declared unconstitutional or having been nullified in most cases. In the case of Cantabria, on 21 May 2018, through a non-legislative proposal, the Spanish parliament were urged to support a motion for measures to boost own energy generation of electricity (scrapping of the so-called sun tax, support for renewables and measures to boost own energy generation of electricity). 
From the point of view of local authorities, Law 27/2013 of 27 December on the rationalization and sustainability of local government, made it impossible for local corporations to act on energy issues. However, from 2014 onwards, various High Court rulings have gradually recognized the competencies of local authorities [15]. These rulings came about as a result of the Community legislative framework on savings and efficiency and compliance with European energy policy objectives and were not due to a legislative change in Spain. At present, there are many local councils that have begun to draw up documents for a "transition to energy sovereignty" or similar concepts, but without any legislation to protect such actions.

With regard to the Basque Country, there has been no attempt to assume competences in the areas of generation, transmission or distribution. Nor does it have any specific or express competence.

\subsection{Energy model in Spain and the Basque Country}

The fundamental characteristics of the Spanish energy model are: high external dependence, as we have seen above, oligopolistic model and no national energy agreement (in some European countries, as we will see later, it has been called transition model or national energy plan). In the case of the Basque Country, there is no active planning and no concrete steps are taken in favor of renewables. The energy dependence in the Basque Country is 92.9\%. All action of the different public bodies has been aimed at efficiency and electrification of energy, but it should be noted that coal has disappeared as the primary fuel for electricity generation in the Basque Country. But the allocated budgets do not support the stated intentions. The model of action in the Basque Country is the same as in the rest of Spain.

\subsection{European Reality}

Five countries have been studied to find out more about the European reality, at least the reality of the countries that has evolved in their energy model through energy transition processes: Germany, Sweden, Denmark, Austria and France. As this year's convention is being held in Coimbra, the situation in Portugal has also been briefly analyzed.

In all the cases studied, there is a clear desire to reduce energy dependence on foreign countries, to adopt renewable energies as an alternative energy source and to reduce emissions. In all cases, legislation has been enacted to promote micro and distributed generation. The generation of employment and the development of technologies for energy production and control are some of the aspects that stand out in the five countries studied. All of them have established a well-planned energy transition model and have given municipalities a very important role both in the obligation to deal with efficiency and energy generation and in the role of making citizens aware and jointly responsible for the importance of energy efficiency (no energy waste at home, in transmission, reduction of emissions, etc.) and the necessary energy transition. The procedure followed involves an infinite number of small sums to make the transition possible, as well as a number of large energy companies that can and will play a relevant role.

In the case of Portugal, investment in renewables has been significant, mainly in hydraulics and wind power. Portugal currently has an energy dependence of $75 \%$ but has committed itself to eliminate all greenhouse gas emissions by 2040. It does not have nuclear energy, but 
its availability of photovoltaic or marine energy is very low; some $97 \%$ of renewable energy is concentrated on hydropower and wind. A peculiarity of Portugal is its high price of electricity (2nd most expensive in Europe) due mainly to the tax and parafiscal charge, which accounts for almost $52 \%$ of the final price.

On 27 July 2018, Portugal, Spain, France, the European Commission and the EIB signed the so-called Lisbon Declaration (2nd summit for energy interconnections) in which they committed themselves to work on and promote the internal market, gas and electricity interconnections, the financing model, energy transition, Euro-Mediterranean cooperation.

\subsection{Good practices in Spain}

As a contrast to good practices in Spain, it has been possible to study unique local energy actions. Three of them were studied in depth: Isla del Hierro in the Canary Islands, Baena in Cordoba and Oñati in Gipuzkoa. Subsequently, it has been possible to study specific performances in Navarre, Madrid, the city of Valencia and Catalonia. In addition, specific projects have also been analyzed in: Ripollet (Barcelona), Ingenio (Las Palmas de Gran Canaria), Rota (Cádiz), Mairena de Alcor (Seville), Trebujena (Cádiz), Albalat dels Sorells (Valencia), Monterrubio de la Serena (Badajoz) and Aviá (Barcelona).

In most cases, the actions are specific in which the availability of resources (external financing) guides one or several singular actions, without a plan of action regarding energy framed in a greater global manner. In the case of the city of Valencia there is an action plan with several strategic lines and programs and actions. In some cases, work is done on the generation (electricity or heat) through biomass, with $\mathrm{CO}_{2}$ emissions, whereas in others it is generated through wind or hydraulics, but with grid injection, as an economic model (investment).

In short, there is a dispersion of actions, some aimed at Energy Efficiency (most), others at generation and others, less, at raising public awareness for their necessary participation in a transitory and renewed model of energy. There is a lack of a national master plan to guide efforts, prioritize actions and promote common action towards energy transition in a coordinated manner. It can be seen that the institutions sign agreements (such as the one mentioned in the Lisbon Declaration), but Spain is currently a country without a specific course in terms of energy non-dependence, the use of the renewable energies and compliance with its obligations of decarburization and non-emissions. As a result of this lack of direction, the actions carried out are uncoordinated and mostly lacking in planning, despite the fact that they are all praiseworthy because they show an interest in sustainability, efficiency and renewable.

\subsection{Development of the preliminary model}

In Phase I, bases of the initial model were developed, in the light of the data obtained in the state of the art (points 3.1, 3.2, 3.3 and 3.4 of this document). In short, the proposed bases were:

Maximize the promotion of energy efficiency and encourage new facilities for the use of RES in the Basque industry.

Intensify the actions in the field of energy saving and expand the facilities for the use of RES in residential and public buildings to reduce energy bills.

Advance in transport and sustainable mobility, knowing that actions in this sector require long-term structural changes, through the promotion of public transport, or the gradual incorporation of vehicles not fueled by oil derivatives. 
Improve the sustainability of the electricity generation park by incorporating new renewable and cogeneration facilities, increasing distributed generation and encouraging own energy generation.

\section{PHASE II. COMPARISON WITH INITIAL MODEL}

\subsection{Analysis of the citizen survey}

Following the methodology of the European Renergy program [10], a survey (personal or telematics) with 34 questions divided into 3 sections was put to 216 families in the region. The results obtained were as follows:

Citizens' knowledge of concepts such as Climate Change, Sustainable Development, Energy Efficiency and Renewable Energies is poor, between $24 \%$ and $30 \%$ of those surveyed (30\%, 24\%, 27\% and 30\%, respectively) had knowledge of these concepts.

Between $93 \%$ and $95 \%$ are in favor of different renewable energies (tidal and hydro energy $93 \%$; solar thermal and photovoltaic $95 \%$, the rest of the renewable energies being between these values). $82 \%$ are against nuclear energy. The main source of information on Energy Efficiency and Renewable Energies are the press (77\%) or the Internet (63\%). Public administrations are of little relevance $(13 \%)$, as are schools $(15 \%)$ and $85 \%$ consider it very important to reduce energy consumption in their home, $87 \%$ perceive that renewable energy installations are expensive and $66 \%$ believe that laws and regulation are a barrier that prevent the installation of renewables. The use of coal as fuel is non-existent ( $0 \%)$, gas being in $87 \%$ of cases the majority fuel for heating. As for citizens' private mobility means, $56.5 \%$ use diesel and $39.8 \%$ petrol. Only $1.8 \%$ use hybrid vehicles.

As a summary of the above, there is little interest and knowledge of the population regarding energy efficiency, renewable energies, climate change and sustainable development. The population's perception of energy is centered on price and the increases it is experiencing, with no clear understanding of the energy model. Energy poverty is not perceived as a problem. Administrations do not take a proactive role with regard to the global nature of the matter. Early training on energy is of little or no relevance. Subsidies largely decide what the preferences of the population are (isolation of housing (Energy Efficiency), purchase of non-polluting vehicles, etc.) but there is no holistic or collective maturity information available to demand a change in the energy model of public administration.

\subsection{Analysis of the municipal sphere}

An analysis has been made of the situation of the town councils of the studied region with regard to action in the field of energy (both in energy efficiency and in generation through renewables and in motivation or public awareness). The results obtained are summarized in Tables 1 and 2.

4.3 Comparison of the results of the preliminary analyses with the European project Renergy

Regardless of the fact that the survey model carried out to assess citizen perception and municipal reality of the region being studied was based on the methodology of the Renergy project, we compared the data obtained in both studies with available information on the European project.

A first similar conclusion is that both citizens and local authorities perceive investments in RES and EE as expensive on which return is uncertain. 
Table 1: Strengths observed in the study at a municipal level.

\begin{tabular}{ll}
\hline & \multicolumn{1}{c}{ Strengths } \\
\hline & Town councils have a joint regional strategy as a starting point, \\
which is currently under review & The Regional Agency participates in the board on energy poverty \\
in Gipuzkoa, organized by the Provincial Council of Gipuzkoa & There has been an energy board in the region, since 2012 \\
There is a culture in place in the development of collaborative \\
projects. \\
Planning and \\
management of the \\
energy model (vision)
\end{tabular}

The general perception is that there is a certain mistrust that RES can cover energy needs, although there is greater trust in known technologies (photovoltaic solar energy or wind power), than there is in less known technologies (geothermal, marine energy).

Lack of information - and sometimes misinformation - is another overlapping main factor. There are no — or very few—campaigns to inform the public about RES, EE or the energy model and its consequences.

Another overlapping factor is the average age of houses; this results in a low EE. In this respect, it should be noted that within the scope of the study some municipalities do have support schemes in place for energy-efficient renovation. 
Table 2: Weaknesses observed in the study at a municipal level.

\begin{tabular}{|c|c|}
\hline \multicolumn{2}{|r|}{ Weaknesses } \\
\hline $\begin{array}{l}\text { Planning and } \\
\text { management } \\
\text { of the energy } \\
\text { model (vision) }\end{array}$ & $\begin{array}{l}\text { There is no definition of the regional energy model (Vision) } \\
\text { Energy is seen as an external element to the municipal strategy } \\
\text { In the town councils, with one exception, there is no formal commit- } \\
\text { ment for the development of energy actions and strategies } \\
\text { Varied municipal political commitment in energy matters } \\
\text { Culture of taking action depending on funding (subsidies) } \\
\text { Municipal action linked to energy is dealt with on an ad hoc basis (be- } \\
\text { cause of a pressing need or an opportunity for a subsidy) } \\
\text { In the majority of town councils, the figure of "energy manager" is } \\
\text { missing, which makes it difficult to evaluate energy projects } \\
\text { Limited capacity to undertake investments in the short and medium term } \\
\text { Total external energy dependence } \\
\text { Low incidence of energy policies in urban planning. Numerous studies } \\
\text { and proposals made remain in project format and no progress is made in } \\
\text { their execution }\end{array}$ \\
\hline $\begin{array}{l}\text { Municipal } \\
\text { management } \\
\text { (efficiency, } \\
\text { generation) }\end{array}$ & $\begin{array}{l}\text { Most towns in the regions have obsolete energy audits, which have } \\
\text { ceased to be a valid element for energy management } \\
\text { The energy and GHG emission indicators have not been updated since } \\
\text { the drafting of the Regional Energy Strategy } \\
\text { Modest and unequal presence of renewable energies in municipally } \\
\text { owned facilities and equipment } \\
\text { Difficulty in developing projects linked to distributed generation net- } \\
\text { works based on renewables } \\
\text { Lack of unification (regional) of fiscal measures aimed at promoting } \\
\text { renewable energies and energy efficiency }\end{array}$ \\
\hline $\begin{array}{l}\text { Sustainable } \\
\text { mobility }\end{array}$ & $\begin{array}{l}\text { Scarce electrification of municipal public mobility } \\
\text { Poor network of cycle paths }\end{array}$ \\
\hline Energy poverty & $\begin{array}{l}\text { Growing number of populations with energy poverty } \\
\text { There is little social awareness in this sense and energy poverty is not } \\
\text { directly related to the energy model } \\
\text { Absence of or poor municipal policies regarding energy poverty }\end{array}$ \\
\hline $\begin{array}{l}\text { Awareness } \\
\text { training and } \\
\text { communication }\end{array}$ & $\begin{array}{l}\text { Absence of continuous training in energy management in town councils } \\
\text { for civil servants } \\
\text { Poor citizen awareness of energy issues (model, transcendence of en- } \\
\text { ergy, impact on the economic system) } \\
\text { Existence of municipal websites with practically no information on } \\
\text { environmental matters and, consequently, also energy }\end{array}$ \\
\hline
\end{tabular}

Countries with the highest gross domestic product are decidedly investing in energy self-sufficiency and use the local sphere as the spearhead of their state policies. In the case study, the municipalities are not in that situation, quite the contrary. 
It can be seen that the decrease in energy consumption during the years of crisis was not due to a greater social awareness of the need for change. The reason for the lower energy consumption was due exclusively to the economic need to save (lower expenditure), or to not being able to pay more for the energy consumed. The economic criterion of savings (not efficiency) was imposed.

One of the conclusions of the European project is the need for education and social awareness about RES and EE. This requirement coincides with the results obtained in the citizen and municipal analysis of the fieldwork carried out.

\subsection{Conclusions of the analysis of the field study and comparison}

The field analyses were carried out (citizen survey and municipal analysis), and comparison with the results obtained in the European project indicates the need to tackle the energy transition carefully and specifically following a series of guidelines:

A municipal environment is ideal to bring about a change of the energy model.

Each country or region has its own characteristics and the model must accommodate these characteristics (cultural, economic, and energy).

Society plays a fundamental role in the drive for change-citizen empowerment-This feature was clearly present in the countries under analysis. A change of the model will not just happen with a change of energy sources; the citizens must be actively involved in the generation of proximity and efficient use of energy. Training and informing citizens about energy (the model and the consequences of the model, in an economic, social and environmental sense) require significant instructional action of government bodies.

In the case studied, citizen disinformation is manifest. But no less important is the municipal public inaction, and although there may be some action in certain senses, this is not organized, planned, let alone coordinated.

As a consequence, the initial model defined in Phase I of the research work has been modified. At the same time, as the beginning of the deployment of the model (Phase III), a program has been designed to draw up a guide of good practices with pupils from schools in the region so as to inform and train them in the long term and at an early age.

\subsection{Modified model}

As has been said before, in Phase I of this work, some preliminary bases were defined to achieve the change of model.

After carrying out the field analysis of the citizens' perception and the municipal situation and comparing the results with those obtained in the European project, the model was modified (Phase II). The seven axes contemplated in the model are synthesized for the region under study (Fig. 2).

Citizen empowerment. Participation of citizens for the analysis and definition of the regional energy model and transition.

Regulatory change to allow distributed generation and own energy generation. Without a regulatory framework that allows or protects the gradual investment of private citizens in RES, the change of model will not be possible. In the case of Spain, the modification of the current legal framework is fundamental and can take place at a municipal level.

Quantitative and qualitative knowledge of local renewable energy possibilities. In order not to repeat the current model of distant generation and transport losses, the possible sources 


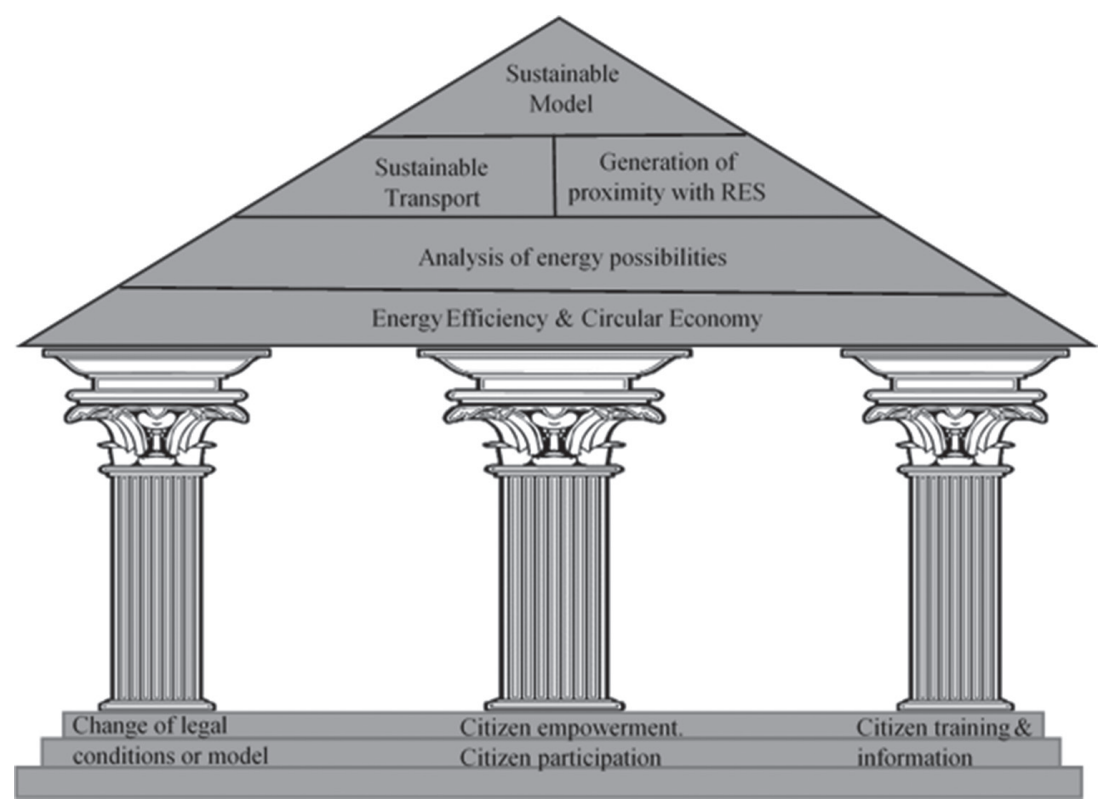

Figure 2. Axes of the modified model.

of renewable primary energy in the environment must be well known. This requires major rigorous and methodical work to minimize as much as possible energy dependence and the establishment of an appropriate mix. A cooperative model is proposed as a reasonable solution to address the needs of scale.

Process of educational implementation (training —information) and citizenship awareness, starting with the youngest.

Energy efficiency as a method to reduce consumption and, therefore, a reduced need for energy generation. The transitional period should accommodate good efficiency practices.

Encourage and promote sustainable transport to reduce pollutant emissions. Closely linked to the energy model are $\mathrm{CO}_{2}$ emissions and polluting gases. The use of sustainable transport will reduce emissions.

The generation of economic activity directly resulting from the development of new technologies for energy efficiency and for generation with renewables. Once again, a cooperation is proposed as a possibility that facilitates the generation of activity.

\section{PHASE III. DEPLOYMENT. IMPLEMENTATION GUIDE}

As a consequence of the obtained analyses and the revision of the model, it was decided to address the deployment of the model in Phase III. To this end, a series of activities were designed related to each of the seven axes defined in the revised model, fieldwork described in the forthcoming paragraphs being one of them. An example of such fieldwork is given in the following paragraphs, related to training and information for citizens which, by its very nature and scope, must be long-term. Through this work, it is intended to promote citizen awareness using educational and sport environments as platforms for the realization of a guide of good practices and energy awareness.

This implementation guide is intended to be a tool that, by means of its implementation in public buildings, positively changes the habits and customs of occupants and also leads to savings in energy consumption. Specifically, the following is pursued: 
To inform about the origin, costs, forms of generation and use of energy in its different forms. It also reports on the environmental consequences of the use of different forms of energy.

To achieve a reduction in energy consumption through changes in user behavior and habits, combined with small maintenance measures and improved energy efficiency.

To raise awareness among those responsible for and users of public buildings of the importance of energy efficiency, reasonable, conscious and responsible use of the building and its installations in general.

To involve and obtain the commitment of users and people in charge of public buildings in the implementation of the defined action measures, and to propose awareness-raising activities.

To reduce energy costs by directing savings to finance other projects, activities or improvements to existing facilities.

To share experiences among the four centers, which can be validated and used by the rest of the centers in the field under study (district). To design an app to visualize savings and results (tangible and intangible).

The following is a concise description of each of the pilots that form part of the project. All of them are public buildings and are located in the region under study, to be precise in the municipalities of Eibar, Elgoibar and Soraluze. The chosen pilots are:

Elgoibar Public School, with 523 pupils and 84 workers. Private School La Salle-IsasiEibar-, with 515 students and 35 workers. Private College of La Salle-Azitain-Eibar, with 335 pupils and 28 workers. Cultural and sports center Arane-Placencia, with 1,105 users and 8 maintenance workers.

The first three are purely for educational purposes, while the fourth, apart from the sports function, has additional cultural, educational and recreational activities.

The method used to select these buildings was based on compliance with the criteria detailed below:

Involvement and interest of the building managers and the Town Hall in the project.

Energy equipment: Participation of the managing persons of each building and of a representative of the users of the building. Each energy team includes the maintenance manager, a municipal representative, the users (students and teachers) and an external energy expert.

Information available about the building: existence of an updated energy audit, energy consumption, other information that may be of interest.

Simplicity in the monitoring and follow-up of the results. Energy saving potential. Impact and replicability potential.

In all of them, a series of parameters have been studied, such as: heating, DHW, air conditioning and lighting systems, energy contributions or available savings or efficiency systems. At the same time, a series of local parameters have also been studied, such as maximum and minimum annual temperature, cloud cover, sunlight and humidity.

With all these, a series of school materials have been made available to the students themselves: information panels of action measures as well as an achievement evaluation form. This field activity is currently being implemented, although the Guide was designed only at the end of 2018.

\section{CONCLUSIONS}

The conclusions obtained from the analysis of the state of the art in Spain are conclusive. The high energy dependence and the increase in $\mathrm{CO}_{2}$ emissions, call for an immediate establishment of an energy transition model, in line with any model that exists in EU countries that 
have undergone an energy transition. In the case of the Basque Country, and the case of the region under study, which is highly industrialized, an efficient planning of a transitory model is required in which the traditional model can coexist for several years with energy generation using renewables, from marine, wind, geothermal and solar generation technologies, as well as of storage and transport. An industrial economic model cannot afford frivolities with energy, but equally cannot afford to lose competitive capacity because of energy costs. The current model is at the point of exhaustion, at a point of no return, without any opening up to a new one, and society is strongly conditioned by the current and, foreseeably, future rigidities. The models studied do not address scale in many cases. The change in dimension from the current centralized model (expansive, unlimited) to a smaller scale model should not be a replication of the traditional model. A major debate involving citizens is due in this regard to find the right model (the examples of good practice refer to various ways of acting, arising from opportunity, need or convenience), but also to contemplate the limits of demand through a thorough and critical approach, without justifying a new model of expansion with the excuse of non-emission of $\mathrm{CO}_{2}$ or proximity.

The reduction of demand is decisive in reducing costs. Some measures will have associated costs of adaptation or diminished welfare [16]. A new energy model must first aim to ensure that we can efficiently meet the strategies of the sustainable economic and social model, distinguishing between objectives and instruments. The circular economy, understood as the efficient use of available resources, seems to make more sense in any small-scale energy model, and stimulates us to measure the energy economy in each of the designed steps more precisely.

The fieldwork made it clear that the public is generally not interested in what sort of energy model is adopted and does not relate energy to climate change, but on the other hand, is very aware of the price of energy, without perceiving that the solution lies in empowerment and in the change of model. There is no room for suppositions; many countries emerge in a transitional process or have long-standing experience. Phase II of this study has served to reconsider the bases of the model, giving more weight to citizens, their participation and their continuous education and information from an early age. This transition must be made, as has been concluded from the studied experiences, with citizen participation as the driving force for change and acceptance of the alternative model because of the major impact.

To this end, phase III of the study was initiated by applying the process of the methodological scheme and experimenting with actions aimed at generating solutions that can be extended to the entire study area. The solutions that are being worked are directed to act from the demand (consumer). Training has been addressed from an early age through the implementation guide and work is being done on a collaborative model of generation-distribution that is incipient, in addition to organizing work groups with citizens. During the coming months, more processes will be designed following the methodological scheme and results will flow from the processes that have already been started.

\section{REFERENCES}

[1] Pelegry, E.A., Basterra, M.L., Mendoza, A.V.D. \& Kamp, B., Afectan los precios de energía a la competitividad de la industria? Orkestra-Instituto VAsco de COmpetitividad, Bilbao, pp. 155-170, 2016.

[2] Aristondo, O. \& Onaindia, E., Counting energy poverty in Spain between 2004 and 2015. Energy Policy, 113, pp. 420-429, Febraury 2018. 
[3] Aristondo, O. \& Onaindia, E., Inequality of energy poverty between groups in Spain. Energy, 153, pp. 431-442, June 2018.

[4] Pelegry, E.A. \& Martínez, I.O., La transición energética en Alemania (Energiewende). Bilbao: ISSN 2340-7638, 2016.

[5] Collin, J.F., La ley de transición energética francesa para el crecimiento verde y la programación plurianual de energía 2016-2023. Real Inst. Elcano; Estud. Int. y estratégicos, p. 130, 2017.

[6] Stocker, A., Großmann, A., Madlener, R. \& Wolter, M.I., Sustainable energy development in Austria until 2020 : Insights from applying the integrated model " e3 . at." Energy Policy, 39(10), Elsevier, pp. 6082-6099, 2011.

[7] Sáfián, F., Modelling the Hungarian energy system-The first step towards sustainable energy planning. Energy, pp. 58-66, 2014.

[8] Danish Energy Agency, Renewables now cover more than $40 \%$ of electricity consumption. Danish Energy Agency, 2015.

[9] Gómez, A. \& Dopazo, C., El ' coste de no hacer ' planificación energética. El alto precio de la improvisación para el sector español de generación eléctrica y para los ciudadanos. Cuadernos de energía, 50, pp. 82-91, 2016.

[10] Cosmi, C., Dvarionien, J., Marques, I., Di Leo, S., Gecevi ius, G., Gurauskien , I. \& Selada, C., A holistic approach to sustainable energy development at regional level: The RENERGY self-assessment methodology. Renewable and Sustainable Energy Reviews, Potenza, Italy, September 2015.

[11] Yin, R.K., Case Study Research and Applications: Design and Methods. London: SAGE Publications, 2003.

[12] Ganzarain, J., Fortea, E. \& de Mecánica, J.A.E.D. Diseño de un metamodelo de innovación de competitividad territorial basado en los modelos de ecosistemas industriales y desarrollo. In 6th. International Conference on Industrial Engineering and Industrial Management, pp. 1169-1176, 2012,

[13] Lasa, I.S., Garaizabal, I.T. \& Egiguren, J.A.E., Desarrollo de un método para la implantación de Ecosistemas Industriales a nivel comarcal. In IX Congreso de Ingeniería de Organización, p. 7, 2005.

[14] Moreno Berrocal, J.M., Regulación y competencias del sector energético español. Escuela de Organización Industrial, [Online]. available: www.eoi.es, 2017. (accessed 30 October 2016).

[15] Corvinos Baseca, P., Competencia normativa municipal en materia de eficiencia energética y energías renovables. Espublico, pp. 23-26, 2015.

[16] Linares, P. \& Labandeira, X., Pobreza Energética en España Análisis económico y propuestas de actuación. 2014. 